JRPIPM. Vol. 2 (2019, no. 2 93-102)

Jurnal Riset Pendidikan dan Inovasi Pembelajaran Matematika

ISSN: 2581-0480 (electronic)

URL: journal.unesa.ac.id/index.php/jrpipm

\title{
The Development Of Mathematics Handout Based On Local Wisdom Nuanced For Secondary Students
}

\author{
Hani Rizkia Putri ${ }^{1}$, Rooselyna Ekawati ${ }^{2}$ \\ ${ }^{1}$ Universitas Negeri Surabaya, haniputri16030174038@mhs.unesa.ac.id \\ ${ }^{2}$ Universitas Negeri Surabaya, rooselynaekawati@unesa.ac.id
}

\begin{abstract}
This study aims to develop a mathematics handout based on local wisdom nuanced to increase the mathematical problem-solving skill of the Secondary students. This research is motivated by the student's ability to solve the social arithmetic problem. This study used four phases of developmental research such as Investigation, Design, Realization, and Test, Evaluation, and Revision. The characteristics of local wisdom were acquired within the design or context in the mathematics handout to develop secondary students problem-solving skills. The results show that the students do the stages of problem-solving by Polya, get the maximum score and show students' positive responses in the questionnaire given. Therefore, it met the proper handout criteria such as valid, practice, and effective. In the future studies, we encouraged to develop learning materials which have a guide to do phases of problem-solving and apply the way to solve some problems in mathematics.
\end{abstract}

Keywords: handout, problem-solving skill, local wisdom

\section{Introduction}

The needs to develop learning material for teaching a certain mathematics topic are increased nowadays. That is because researchers and mathematics educator realize that learning materials play very important roles in building students' mathematics problemsolving skill. Studies on mathematical problem-solving become an intensive view of experts mainly dealing with essential questions regarding the teaching and learning of mathematics [1]. Gravemeijer [2] mentioned that if we want students to reinvent mathematics by doing mathematics, teachers have to adapt to how their students reason and help them build on their thinking. Therefore, in order to have a broader insight on the needs of teacher related to problem-solving, a handout is effectively to teach problemsolving by students' thinking [3].

Handout consists of two components: the identity that contains the identity of the handout and the material that explain the main material and also the exercise. Uyun et al developed mathematics handout before based on problem-based instruction [4]. Then, Rahayuningsih also developed mathematics handout based on guided inquiry model [5]. So, some of the handouts were developed by a different model in teaching. The mathematics handout for teaching material will be an effective way that motivates for the students to learn, such that based on local wisdom [6]. According to the Regulation of the Minister of Education and Culture of the Republic of Indonesia, learning materials should motivate to learn from the local, national, or international, and corresponding to the 
characteristics and learner learners [7]. The learning material which contains local content will make students know the local content in their areas, especially Java Island, Indonesia. But, the fact of learning materials in Indonesia is the lack of local wisdom and less original content. This local content is rarely found in some textbooks, even though mathematics has always been part of human culture. So, the learning material according to Indonesian government regulations in addition to the learning materials should contain local content from the region. This teaching material will be the complementary instrument that increases the mathematical problem-solving skill by local wisdom content in some problems that will be solved by the students. This handout also gives a simple explanation or the main point of the topic that will not make the students bored, especially when they learn about the social arithmetic topic.

The social arithmetic topic was chosen because based on the early investigation by interviewing some secondary students, they have a problem to solve the social arithmetic problem. They think that this material is full of formula and they must memorize all of the formulae. But, when they memorized all of them, then they meet the developed problem, they can't use the formula that was given to solve the problem. It happened because they just memorize without getting the main point of this material. So, they need something to acquire their problem-solving skill by mathematics handout that will give the main point and some problem with local wisdom nuanced. This learning material that should be made is rarely found in math textbooks. Local wisdom owned by Indonesia and it will make the learning activity more fun than before. So, it can acquire the students' problem-solving skill.

Concerning problem-solving skill in mathematics, the seminal contribution of Polya [8] highlights four steps: understanding the problem, devising a plan, carrying out the plan, and looking back. Even though this model originates in mathematics. Other frameworks have specific foci. Oser and Baeriswyl's [9] model, for example, that consists of five steps: generating a problem, specifying a problem, finding possible ways to solve the problem, testing these ways, and putting the solution into a larger context. Merrill et al. also contribute to arrange steps in problem-solving [10]. They focus on the following general steps: identifying a problem, defining the problem, generating solutions, evaluating/choosing solutions, and assessing the outcome. Important for that argument, showing how students acquire the problem-solving skill.

All the above mentioned steps of problem-solving become a reference for the researcher to evaluate how the mathematics handout based on local wisdom nuanced can acquire the students' mathematics problem-solving skill. The research question is "How can the Mathematics Handout with Local Wisdom Nuanced increase the Problem-solving Skill of Secondary School Students in Social Arithmetic Topic?

\section{Method}

This research is a type of development research, i.e. Development of Mathematics Handout Based on Local Wisdom. The development model which used refers to Plomp [11], that consists of five steps: (1) preliminary investigation, (2) design, (3) realization, (4) test, evaluation, and revision, (5) implementation. But, in this case, the researcher only does up to the $4^{\text {th }}$ phase, such as test, evaluation, and revision. The subject of this research is the student of junior high school. In detail, many subjects involved are 2 students that can't show problem-solving skill to solve some mathematics problem. Students involvement as a subject is to know the level of validity, practicality, and effectiveness of this handout so that it includes good criteria [12]. The instruments are the validation sheet to obtain data on the validity of handouts, pre-test, post-test, and questionnaire to know the students' response. 
There are two indicators, such that indicators of local wisdom nuanced and indicators of the proper handout.

I. Indicators of local wisdom nuanced on the mathematics handout are as follows:

a. Design of the handout which is about local wisdom in Indonesia, especially in Java Island.

b. The mathematical problem was given is about tradition or local wisdom in Java.

II. Indicators of the proper mathematics handout are as follows:

a. Validation, based on the evaluation by expert validators which shown that the mathematical handout based on local wisdom nuanced suitable for use in learning mathematics.

b. Practical, based on the activities was done by students, the activities must show the problem-solving process by Polya, such that

1. understanding the problem

2. devising a plan

3. carrying out the plan, and

4. looking back.

c. Effective, based on the responses of the students by the questionnaire which shown positive responses, also based on the score of student's exercise which shown the score more than 80 .

\section{Result and Discussion}

\subsection{Preliminary Investigation}

In this phase, the researcher analyzes the curriculum, students, and the material. The preliminary stage was conducted on 2 students who were studying in junior high school who can't show the problem-solving process. They were asked to answer the mathematics questions from researcher's interview. They used the K-13 curriculum which gives priority in student's activity, and the teacher just for a facilitator who help the students when they felt difficult to solve the problem. Based on the result of the interview the students, they have a problem to memorize the formula of the arithmetic topic. So, the researcher chooses the social arithmetic topic.

\subsection{Design}

In this phase, the researcher designs the product, such that the design of mathematics handout and the problem so that it can be based on the local wisdom nuanced. Then design the instruments which used to evaluate the mathematics handout, such that the validation sheet of material and media, questionnaire for students, and the pre-test. For post-test, the researcher uses the problem in the exercise which shown at the end of the handout.

\subsection{Realization}

This handout was designed in simple language and complemented by examples of real problems about social arithmetic in student life that contain the context of local wisdom in Java. Handout is considered good if it has been properly applied in learning, with evidence that it does not cause problems when tested in a limited manner and get positive responses from students. Handout developed has been adapted to the basic elements that making up a handout, the identity and material. The following is a part of the handout design that shows the nuances of local wisdom. 


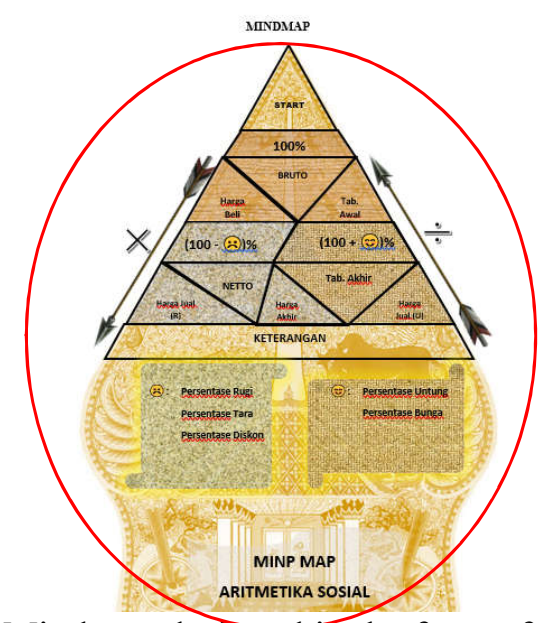

Picture 1 Mindmap designed in the form of a gunungan

So that corresponding with the criteria of local wisdom nuanced

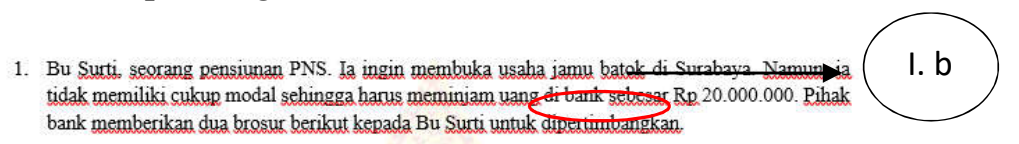

bank memberikan dua brosur berikut kepada Bu Surti untuk drperdumuangkan
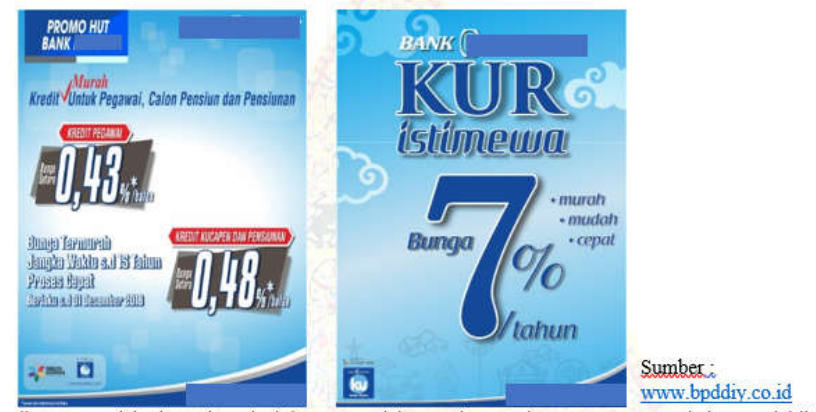

Jika Bu Surti ingin melunasi pinjamannya dalam waktu 5 tahun, tawaran manakah yang lebih menguntungkan bagi Bu Surti?

Penvelesaian:

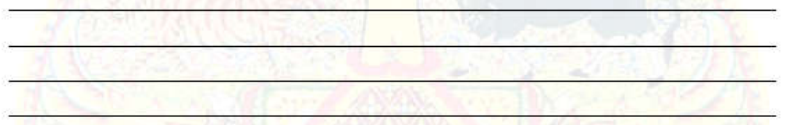

Picture 2 Presenting problems with the context of local wisdom Namely jamu batok [13], local wisdom of Java

2. Mbak Minah adalah seorang pedagang pecel. Satu bulan lagi menjelang lebaran dan Mbah Minah belum memiliki uang lebih untuk itu mengingat harga kebutuhan barang nokok semakin mahal. Badahal ia membutuhkan uang sekitar Rp. 2.000 .000 untul cimjo tupatom, dan memberi uang

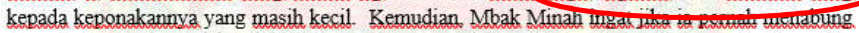
di suatu bank sebesar Rp 1.000 .000 dua tahun yang lalu. Jika bank teesebut memberikan suku bunga $6 \%$ per tahun. Apakah tabungan tersebut cukup untuk memenuhi keinginan Mbak Minah? Penyelesaian:

Picture 3 Presenting the context of Javanese local wisdom in practice questions Namely cinjo, tupatan, and the tradition of giving money as a form of gratitude 
The Development Of Mathematics Handout Based On Local Wisdom Nuanced For Secondary Students

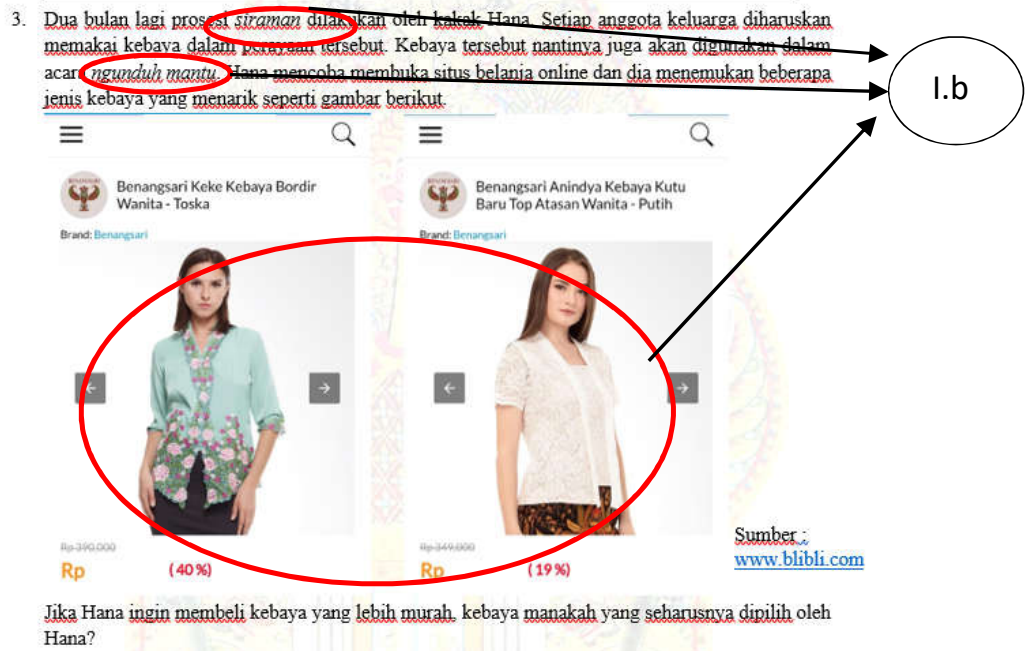

Picture 4 Showing the context of Javanese local wisdom

Namely siraman [14] and ngunduh mantu [15] to welcome the arrival of new families, as well as images of kebaya which is an icon of Javanese local wisdom [16]

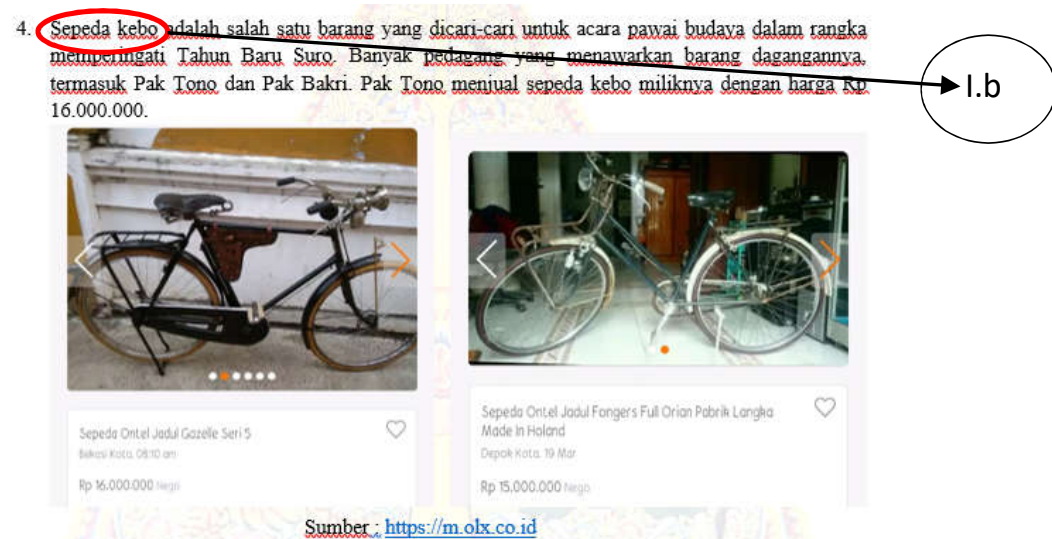

Sedangkan Pak Bakri meniual sepeda kebo miliknva seharga Rp 15.000 .000 , namun ia harus menambahkan beberapa accesoris yaitu bup depon, emblem, bel kodok, dan sadel gelung dengan spesifikasi harga sebagai berikut. Jika Pak Tono membeli sepeda tersebut seharga Rp 800.000 dan Pak Bakri membeli sepeda tersebut seharga Rp 650.000 , maka pedagang manakah yang lebih banxak mendapat keuntungan?

Picture 5 Showing the context of Javanese local wisdom

Namely Kebo bicycle as a form of local wisdom in colonial times, so it can motivate students

and

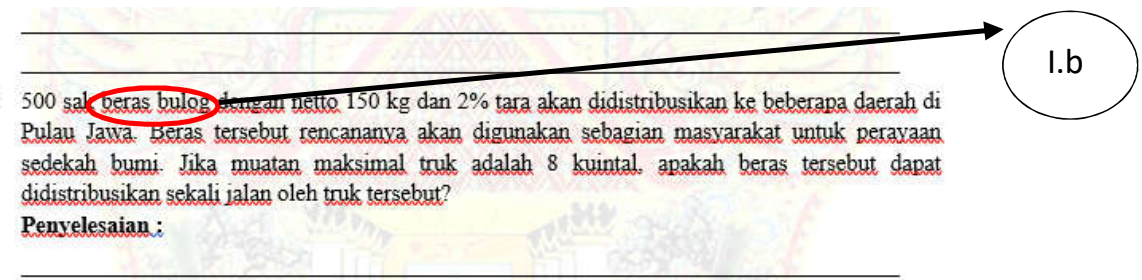

Picture 6 shows local wisdom

Bulog rice, which is a process of distributing citizen crops throughout Indonesia Based on some of the descriptions above, it can be seen that these mathematical handouts are nuanced with local wisdom, both in terms of design and the context of the 
problems presented, following the indicators of the local wisdom nuanced in the mathematics handout. At this stage is, the handout being developed is called prototype 1. Meanwhile, prototype 1 was given to some expert validators so that it can be known the validity of content, constructs, and languages. The validation results from the validator show that the handouts developed are included in the valid category with several revisions. Furthermore, at the same time, the researcher revised the following handout: correction of some typo, the use of capital letters, more effective sentence writing, and drawings are made more clearly. The result of this was used to revise prototype 1 to prototype 2 . Thus, mathematics handout based on local wisdom nuanced meet the aspects of validity.

Then, the handout was tested to students on a limited basis, the subjects taken were two junior high school students in Surabaya. Limited basis trial aims to determine the response of subject students to the practice of handout that is reviewed from their opinions on the preparation of handout as well as the validity of handout viewed from the observation of learning activities. Furthermore, the researcher performs analysis prototype 2 evaluation with small group subjects. It aims to obtain an overview of the various responses of subject students to the learning activities that are applied by the mathematics handout based on local wisdom nuanced. Based on the results of the researchers 'observations and the results of the students' work, it shows how the problemsolving process can be done. According to Polya, the problem-solving steps include (1) understanding the problem, (2) devising a plan, (3) carrying out the plan, (4) looking back.

The following are the sample results of student work.

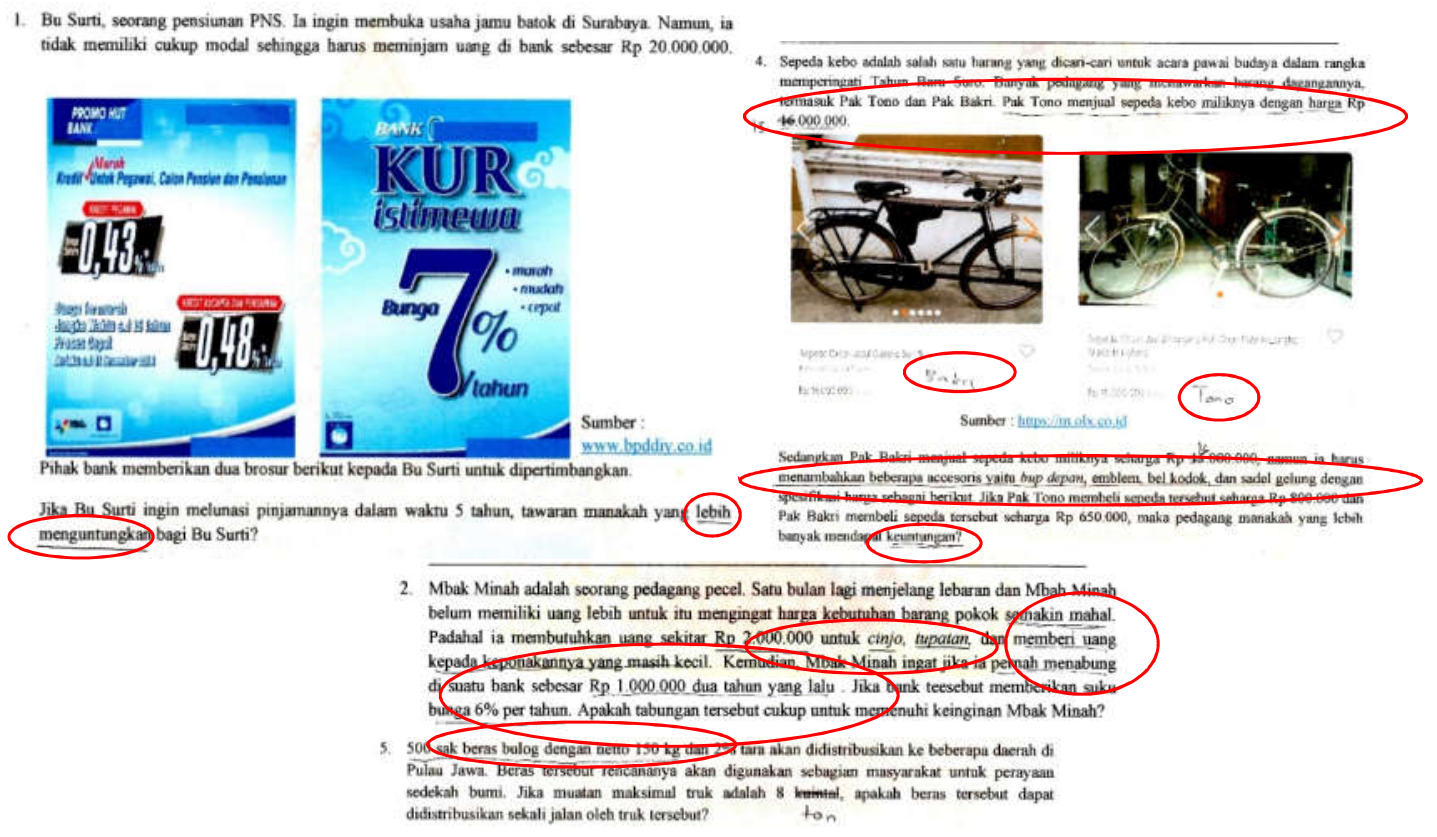

Picture 7 The process of students in understanding a problem, which is the first stage in the problem-solving process (II. b. 1)

Detail of the solution that solved by student are as follows : 


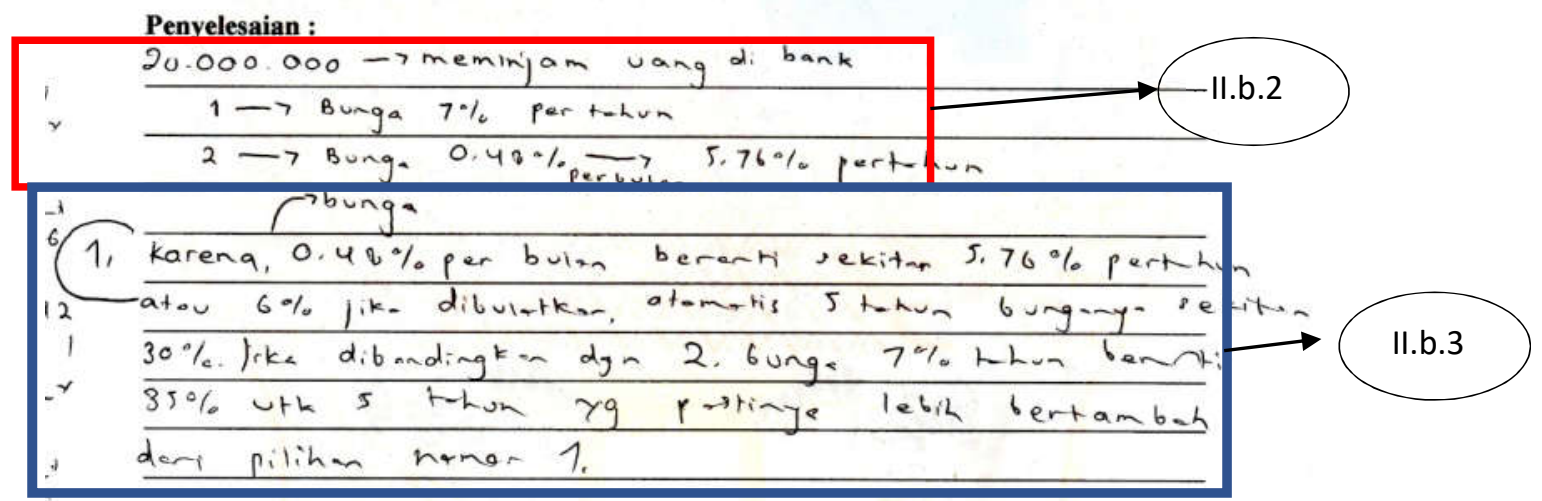

Picture 8 Answer student for the first number

For the first problem, the student showed the problem-solving steps by Polya. In the picture above, students have shown the first steps by underlined the point of the problem to understanding what is the problem that should be solved (II. b.1). Then, she wrote the plan such that they identified the main problem and developed what the next problem (II.b.2). She compared the previous information and carrying out the plan to get the conclusion (II. b. 3)

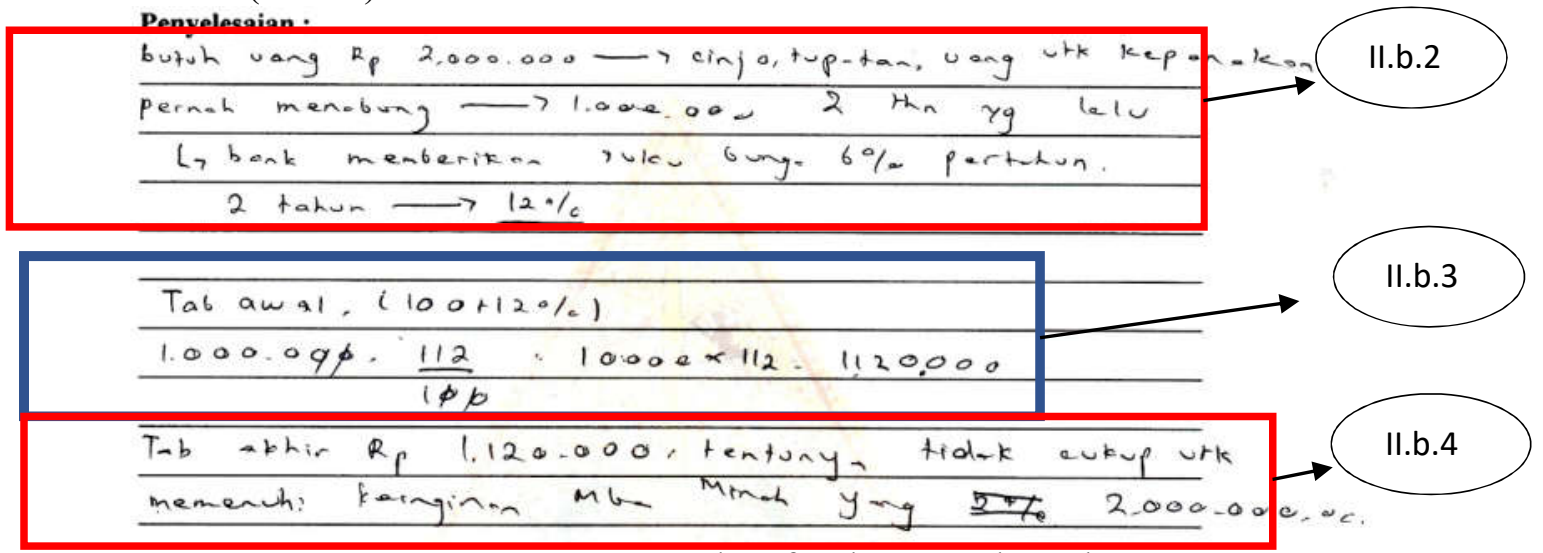

Picture 9 Answer student for the second number

In the second problem, the student always understanding the problem by underline the main point of the problem (II. b. 1). Then, devising a plan (II . b. 2) to get the interest rate. Using the interest rate, students can solve the problem by a formula given by the researcher in the mind map section, so the students carrying out the plan (II.b.3) to get the answer. Using this answer, they can make a decision to solve the problem by re-check the first information was given and the final result (II.b.4).

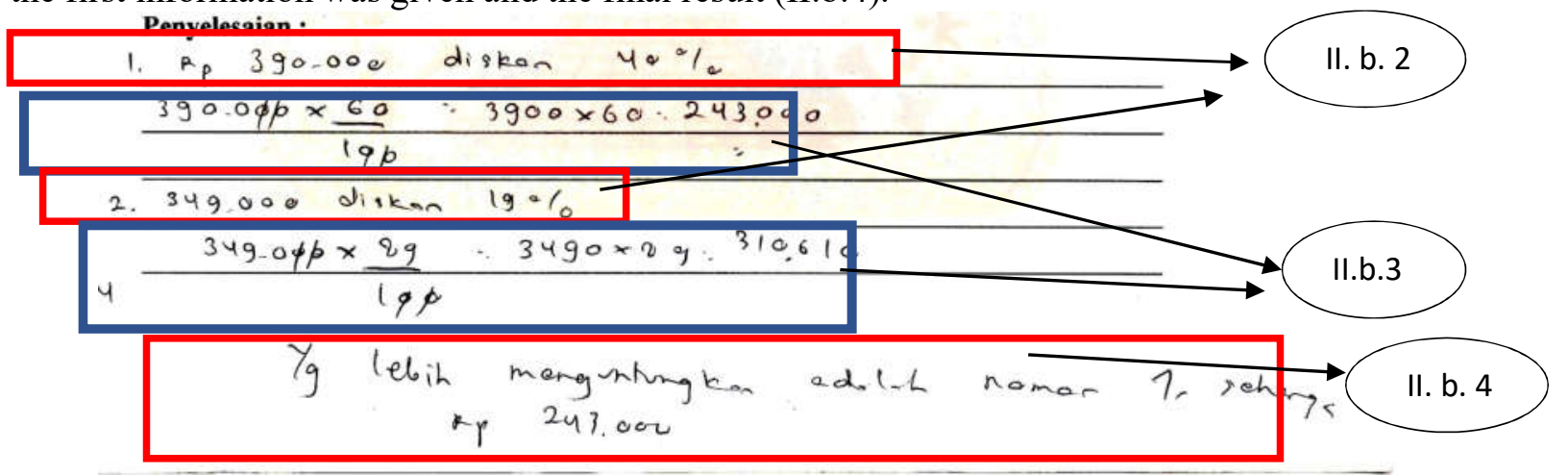

Picture 10 Answer student for the third number 
In the third problem, students get the point of this topic. So to understanding the problem, students scanning the questions (II.b.1) and wrote the discount to devise which formula that can be used for this problem (II.b.2). Then, they used the chosen formula to get the result (II.b.3). after that, the students re-check and compared between the first and the second result to make a decision (II.b.4)

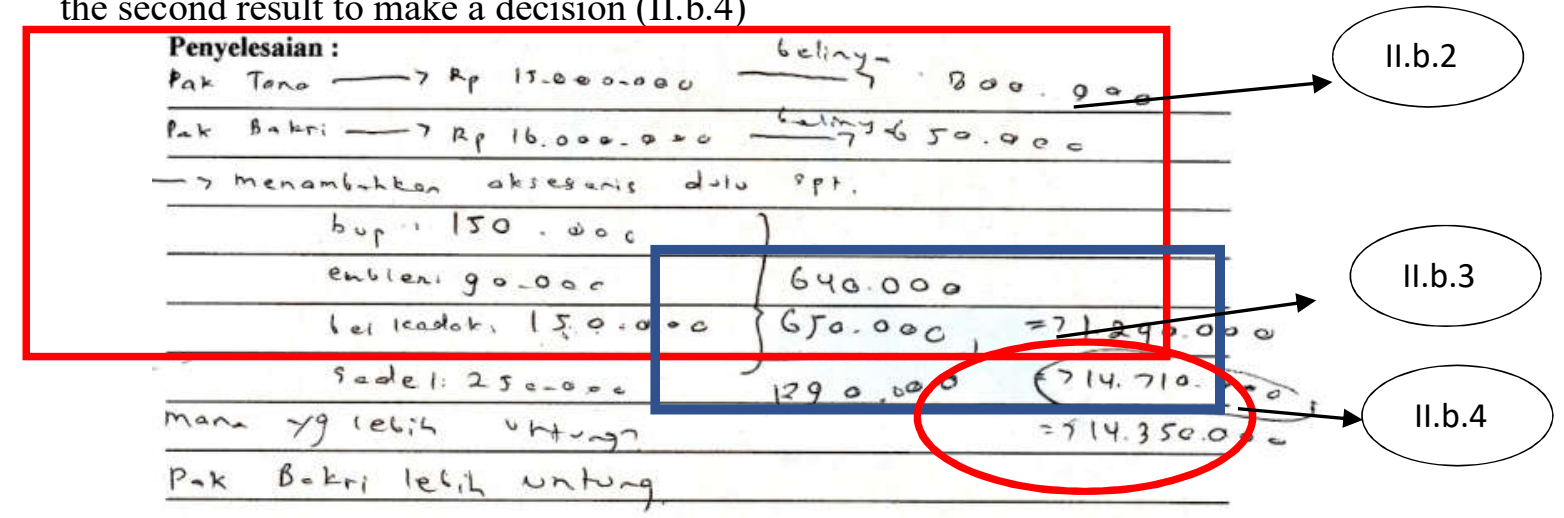

Picture 11 Answer student for the forth number

In the fourth problem, like the previous problem, they understanding the problem by scanning and underlined the main point (II.b.1) and wrote the main point to devise a plan (II.b.2). Then, students calculate the result by the plan (II.b.3). After that compared the result to make a decision (II.b.4).

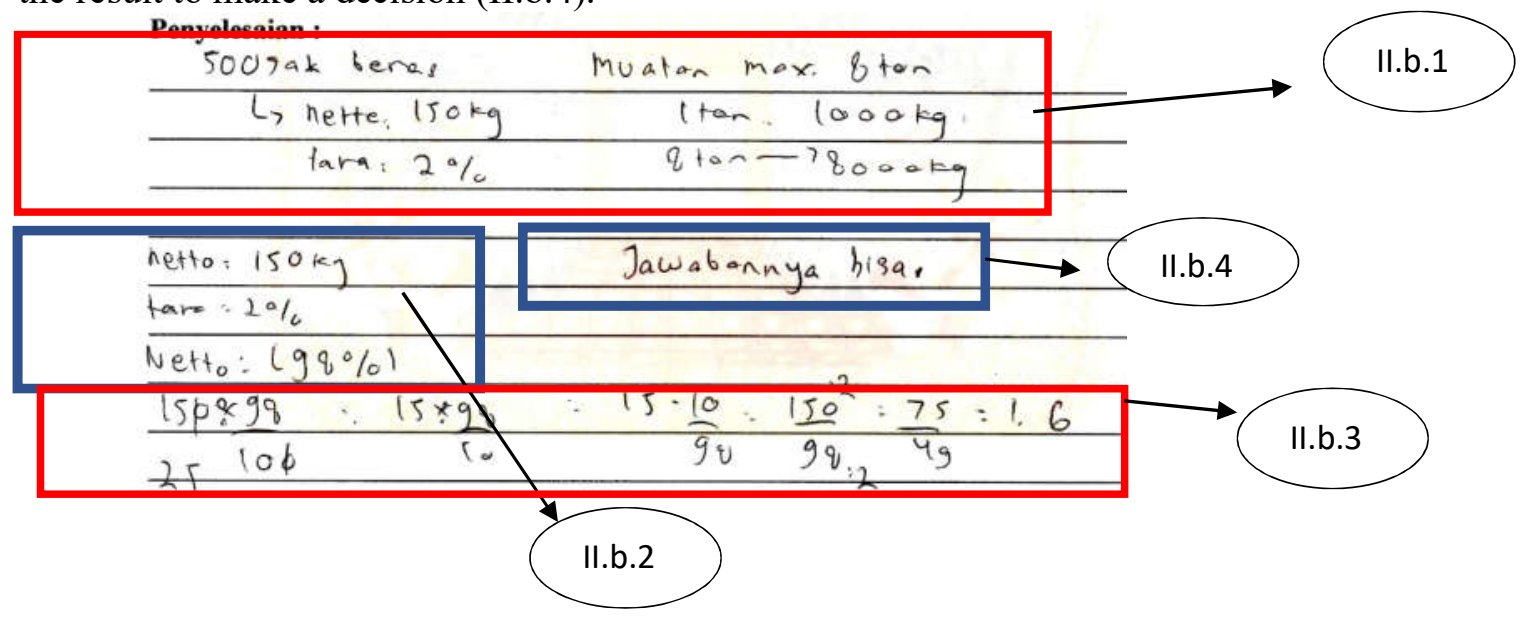

Picture 12 Answer student for the third number

In the last problem, the students shown all of the problem-solving steps by Polya. Students understanding the problem by underline and write the main point (II.b.1). Then, students devising a plan by writing the components which can be applicated in the formula (II.b.2) and using the formula to calculating the result (II.b.3). After that, the students doing re-check to make a decision (II.b.4). But the students have the wrong answer because of carelessness when calculate the number. By observation and interview the students, actually the student re-check the result but the student said that had error to remember cancelation in the division case was not allowed.

Furthermore, teaching material is said to be practical if it can be used in the field according to experts and practitioners and based on the implementation of teaching material. The figure above shows the students have carried out the stages of problemsolving by Polya, where the inspection stage is returned with the process of re-checking the results of the process. That way, this handout can improve students' problem-solving abilities includes knowledge of students' problem-solving, successful problem-solving 
characteristics, and the process of problem-solving. From these problems, students solve problems according to the steps expected by the researcher. For that, Peker [17] argues that learning problem-solving needs to be done through activities such as sharing experiences, discussing each other, and implementing problem-solving strategies in the right place. Based on the data analysis, learning activities using the handout in a small group gave positive responses from the students. Thus, it can be concluded that the developed handout meet the aspects of practice.

From the questions that have been completed by students, a value of 9.5 is obtained. Students do not get a perfect score due to a calculation error in solving question number 5. Besides, based on the student response questionnaire, the results show that the appearance aspects 3.17 , material aspects 3.4 , and language aspects 3 . It can be said that according to the student's assessment the handout good quality. Furthermore, analysis of students responses by interview to the mathematics handout developed showed a positive response. These results indicate that the response of the student in the positive category. Based on the description, it can be concluded that the developed mathematics handout meet the aspect of effectiveness.

\section{Conclusions}

To sum, the mathematics handout based on local wisdom nuanced meet the aspects of validity, practically, and effectiveness. Validity is indicated by the experts' judgments indicating that this handout is good to be implemented. Practically is demonstrated by the results of the implementation of learning using mathematics handout based on local wisdom nuanced. Effectiveness of this handout is shown by the score of student and the positive response of the student to the handout developed.

In the future studies, we encouraged to develop learning materials which have a guide to do phases of problem-solving and apply the way to solve some problems in mathematics.

\section{Bibliography}

[1] Siswono, T. Y., Kohar, A. W., Hartono, S., Ekawati, R., \& Wijayanti, P. 2018. Developing learning materials supporting teachers' understanding on mathematics problem-solving knowledge for teaching. Mathematics, Informatics, Science, and Education International Conference (MISEIC 2018). 157. Atlantis Press. Retrieved from http://creativecommons.org/license/by-nc/4.0/

[2] Gravemeijer, K. 2015. Development of mathematics teaching: design, scale, effects. MADIF9 (pp. 1-3). Linkoping: SMDF.

[3] Rahmayani, F., Hindun, I., \& Huda, A. M. 2015. Pengembangan Handout Berbasis Kontekstual pada Pelajaran Biologi Materi Bioteknologi Untuk Siswa Kelas XII SMK Negri 02 Batu. Jurnal Pendidikan Biologi Indonesia, 1(1), 47-59. doi:10.22219/jpbi.v1i1.2302

[4] Uyun, Q. 2017. Pengembangan Media Handout Segitiga dengan Model Problem Based Instruction. MUST: Journal of Mathematics Education, Science and Technology, 2(1), 115-128.

[5] Rahayuningsih, Agustin. 2017. Pengembangan Handout Matematika Berbasis Inkuiri Terbimbing Kelas V SD/MI Semester 2. Tesis. Tidak dipublikasikan. Yogyakarta: Universitas Islam Negeri Sunan Kalijaga.

[6] Dazrullisa. 2018. Pengaruh Pembelajaran Matematika Berbasis Kerifan Lokal Terhadap Minat Belajar Siswa. GENTA MULIA, 9(2), 141-149. 
[7] Kemendikbud. 2016. Peraturan Menteri Pendidikan dan Kebudayaan Republik Indonesia No. 22 Tahun 2016 tentang Standar Proses Pendidikan Dasar dan Menengah. Jakarta: Peraturan Menteri Pendidikan dan Kebudayaan Republik Indonesia.

[8] Polya, G. 1957. How to Solve It. 2nd ed. Princeton, NJ: Princeton University Press.

[9] Oser, F. K., \& Baeriswyl, F. 2001. Choreographies of Teaching: Bridging Instruction to Learning. In AERA's Handbook of Research and Teaching (pp. 10312065). Wahington, DC: American Educational Research Association.

[10] Merrill, K. L., Smith, S., Cumming, M., \& Daunic, A. 2017. A Review of Social Problem-Solving Interventions: Past Findings, Current Status, and Futue Directions. Review of Educational Research, 87(1), 71-102. doi:10.3102/0034654316652943

[11] Khabibah, Siti. 2006. Pengembangan Model Pembelajaran Matematika dengan Soal Terbuka Untuk Meningkatkan Kreatifitas Siswa Sekolah Dasar. Disertasi. Tidak dipublikasikan. Surabaya: Program Pasca Sarjana Universitas Negeri Surabaya.

[12] Brata. 2016. Pengembangan Perangkat Pembelajaran Kooperatif Tipe Think Talk Write dengan Strategi Motivasi Arcs pada Materi Geometri Kelas VII SMP. Tesis. Tidak dipublikasikan. Surabaya: Program Pasca Sarjana Universitas Negeri Surabaya.

[13] Suryanto, I. 2019. Jamu Batok Yogyakarta, Warisan Budaya Bangsa. Yogyakarta: Kompasiana.

[14] Gazalba, S. 1975. Menghadapi Soal-Soal Perkawinan. Jakarta: PT Pustaka Antara. Retrieved from wikipedia.org.

[15] Tryaningrum, M. 2016, November 13. Syariah UIN Malang. Retrieved from syariah.uin-malang.ac.id: https://syariah.uinmalang.ac.id/index.php/komunitas/blog-fakultas/entry/tradisi-ngunduh-mantudalam-kebudayaan-perkawinan-masyarakat-jawa

[16] Wikipedia. 2006, Juli 17. Retrieved from wikipedia.org: https://id.m.wikipedia.org/wiki/Kebaya

[17] Peker, M. 2009. The New Educ. Review, 95. 